\title{
PENGARUH PERSEPSI KUALITAS PRODUK, PENGALAMAN BELANJA ONLINE, DAN AKSES INFORMASI TERHADAP NIAT BELI ULANG ( Studi Pada Pembelian Online Sepatu Sepak Bola Merek Specs Di Kota Denpasar)
}

\author{
I Wayan Sudangga Aditya ${ }^{1}$ \\ Made Jatra ${ }^{2}$ \\ ${ }^{1,2}$ Fakultas Ekonomi dan Bisnis Universitas Udayana (Unud), Bali, Indonesia \\ e-mail : wayansudangga@gmail.com
}

\begin{abstract}
ABSTRAK
Penelitian ini bertujuan menjelaskan pengaruh dari persepsi kualitas produk, pengalaman belanja online, dan akses informasi terhadap niat beli ulang. Penelitian ini dilaksanakan di kota Denpasar yang melibatkan 100 responden. Untuk memperoleh data, penelitian ini digunakan kuesioner, observasi dan wawancara. Teknik analisis data yang digunakan regresi linier berganda. Hasil penelitian ini menyatakan kualitas produk, pengalaman belanja online, dan akses informasi berpengaruh positif signifikan terhadap niat beli ulang. Pihak manajemen Specs hendaknya memberikan keterangan yang detail pada setiap produknya, informasi yang selalu update, memeriksa kembali dengan teliti barang yang dikirim agar konsumen tertarik melakukan pembelian ulang dan tidak mendapatkan informasi yang salah.
\end{abstract}

Kata kunci : persepsi kualitas produk, pengalaman belanja online, akses informasi, niat beli

\begin{abstract}
This study aims to explain the influence perceptions of product quality, online shopping experience, and access to information on repurchase intentions. This research was conducted in Denpasar involving 100 respondents. To obtain data, this study used questionnaires, observation and interviews. Data analysis techniques used multiple linear regression. The results of this study state that product quality, online shopping experience, and information access have a significant positive effect on repurchase intention. Specs management should provide detailed information on each product, information that's always updated, carefully re-examine the goods sent. that consumers are interested in repurchasing and not getting the wrong information.
\end{abstract}

Keywords : perception of product quality, online shopping experience, infromation access, purchase intention 


\section{PENDAHULUAN}

Internet telah diibaratkan sebagai sarana media yang baik dan tepat untuk perusahaan berkomunikasi langsung kepada konsumen, serta upaya dalam menarik perhatian serta membuat ketertarikan pembeli terhadap produk (Oetomo \& Santoso, 2015). Hadirnya online shop telah memberi pembeli pilihan alternative lain untuk berbelanja selain membeli di toko konvensional (Yuliati \& Simanjuntak, 2011). Sebagai salah satu media perantara untuk berbisnis, keunikan internet memberi kemungkinan suatu perusahaan untuk membuat suatu lingkungan bisnis dalam berbelanja online yang interaktif dan memberikan kesempatan calon pembeli untuk mencari informasi, mengumpulkan informasi dan mengevaluasi informasi, menilai opsi beli, kemudian langsung membeli produk tersebut demi kenyamanan pembeli sendiri (Suki, 2013).

Gaya hidup dari masyarakat dewasa ini kemungkinan berubah dikarenakan pengaruh akan perkembangan dari teknologi yang terus berjalan, perubahan yang mencolok akan perkembangan dari teknologi yaitu gadget, serta kecenderungan dalam beraktivitas di internet seperti melakukan pembelanjaan secara online yang kemudian lebih sering disebutkan sebagai belanja online (Setiowati et al., 2012). Belanja secara online sudah menjadi bagian dari kehidupan masyarakat dewasa ini karena dinilai sangat mudah dan praktis. Biasanya yang menggunakan internet ialah orang yang mempergunakan dan meluangkan waktunya untuk mengirim $e$ mail, melaksanakan browsing dan berbagai macam pencaharian lainnya seperti untuk keperluan pendidikan dan bisnis (Sutedjo dalam Gendis et al., 2009). 
Belanja online adalah suatu proses transaksi dari konsumen yang langsung berbelanja suatu barang, serta jasa maupun hal lainnya melalui penjual yang dilakukan secara interaktif serta real time dengan perantara dari media yang disebut internet. Belanja online yaitu salah satu dari bentuk perdagangan melalui elektronik yang dipakai untuk melakukan kegiatan transaksi dari penjual kepada penjual atau dari penjual ke konsumen (Halim., 2010). Toko online ibarat salah satu bentuk dari penjualan dan pembelian yang melalui perantara jejaring sosial yang memudahkan agar pembeli tidak datang lagi langsung ke store untuk mengecek dan membeli apapun yang mereka inginkan, dikarenakan adanya berbelanja melalui perantara media online bisa dengan mudah melihat dan memilah barang yang diinginkan langsung dari internet serta kemudian melakukan pemesanan barang tersebut sesuai kehendak dengan melalui transfer uang yang kemudian barang akan dilakukan pengiriman oleh penjual sampai dirumah pembeli (Meskaran et al., 2013). Toko online adalah bentuk perubahan yang disajikan oleh internet dalam segi inovasi untuk berbelanja dengan mudah. Toko online memberikan berbagai kemudahan dalam proses transaksi yang pada setiap kesempatan menjadi wacana dalam perbincangan oleh masyarakat (Nurtjahjanti, 2010).

Perusahaan berlomba-lomba untuk menciptakan suatu produk guna memenuhi kebutuhan manusia yang kian lama terus berkembang. Keinginan pasar yang terus meningkat mengakibatkan adanya keragaman dalam permintaan yang diinginkan konsumen. Dengan adanya hal itu manajemen perusahaan dituntut untuk terus bersaing sehingga perusahaan bias terus mempertahankan pelanggan 
lama serta akan mendapat pelanggan baru. Kemajuan dari teknologi serta informasi yang terus berkembang mengakibatkan suatu persaingan antar perusahaan. Demikian halnya persaingan penjualan sepatu olahraga secara online di Indonesia. Bisnis sepatu olahraga sangat ketat dengan adanya berbagai merekmerek luar serta merk lokal yang turut ikut meramaikan pangsa pasar sepatu olahraga di Indonesia.

Pembelian sepatu olah raga khususnya sepatu sepak bola tergantung dari kualitas dari produk itu sendiri. Kualitas yang baik akan menjamin minat konsumen untuk membeli produk sepatu olah raga dari merek apapun itu. Setiap konsumen tentu saja akan memilih suatu produk yang akan mampu memuaskan keinginannya atau dalam kata lain suatu kualitas yang baik. Kualitas yang baik akan membuat pertimbangan lain dari konsumen kenapa pada akhirnya mereka memilih untuk membeli sepatu sepak bola tersebut melalui pembelian online ataupun secara langsung. Penjualan sepatu olahraga khususnya sepatu sepak bola di Indonesia tahun 2017 diduduki tiga merek yang menempati peringkat teratas adalah sepatu merek Nike, Specs dan Adidas. Dalam skala penjualan nasional, ketiga merek tersebut tentu saja memiliki kualitas yang baik sehingga mampu bersaing dan menarik minat beli dari konsumen. Namun persaingan yang ketat pada industri sepatu olahraga tersebut juga terjadi di Bali yang dapat ditinjau berdasarkan data penjualan online sepatu sepak bola per tahun 2017 di Kota Denpasar yang ditunjukkan pada Tabel 1. 
Tabel 1.

Data Penjualan Online Sepatu Sepak Bola per Tahun 2017 di Kota Denpasar

\begin{tabular}{cccccc}
\hline & \multicolumn{3}{c}{ Toko Olahraga Populer di Kota Denpasar } & \\
\cline { 2 - 5 } MEREK & $\begin{array}{c}\text { Istana } \\
\text { Sport }\end{array}$ & $\begin{array}{c}\text { Hawaii } \\
\text { Sport }\end{array}$ & Arena Sport & Sport Station & \multirow{2}{*}{ Jumlah } \\
& 1602 & 1672 & 0 & & \\
\hline Nike & 1480 & 0 & 1603 & 2097 & 5252 \\
Specs & 1061 & 1356 & 0 & 1536 & 3953 \\
Adidas & 678 & 0 & 0 & 480 & 1158 \\
Reebok & &
\end{tabular}

Sumber: survey pada Bagian Penjualan Toko

Tabel 1. menunjukan jika pembelian konsumen terhadap sepatu sepak bola Specs sangat tinggi. Banyaknya pilihan dari penjual yang menawarkan produk sepatu sepak bola tersebut secara online memberikan kesempatan konsumen untuk memilih barang yang diinginkan sebelum akhirnya memutuskan untuk membeli sepatu tersebut. Salah satunya caranya adalah dengan membandingkan penawaran dari situs yang satu dengan situs lainnya untuk produk yang sama. Hal tersebut yang dimanfaatkan Specs walaupun terdapat banyaknya pesaing produk sepatu olahraga di Kota Denpasar, Specs mampu mengungguli persaingan dari merek luar negeri seperti Adidas dan Reebok. Pembelian online yang menjadi tren konsumen saat ini merupakan kesempatan yang bagus bagi produsen sepatu olah raga khususnya sepak bola, karena konsumen lebih dapat melihat detil dari produk tanpa harus datang ke toko. Dengan tingginya angka pembelian dari sepatu sepak bola Specs, ini berarti Specs mempunyai persepsi kualitas produk yang baik di mata konsumen. hal tersebut tentu saja dapat mempengaruhi niat beli ulang konsumen secara online untuk melakukan pembelian produk sepatu sepak bola di Kota Denpasar.

Specs giat melaksanakan suatu promosi above the line, dengan memasang iklan di televisi serta media lainnya. Selain terus melakukan iklan, Specs juga giat 
menggelar promosi aktivasi merek. Misalnya, Specs melangsungkan pelatihan klinik, melakukan kerja sama dengans sekolah sepak bola, lainnya Specs juga sering mensponsori kejuaraan - kejuaraan sepak bola di berbagai daerah di Indonesia. Dengan giatnya promosi yang dilakukan serta kegiatan yang dilaksanakan sering mendapat suatu perhatian lebih dari masyarakat sebagai konsumen membuat citra dari Specs semakin kuat tertanam di benak konsumen yang ada. Sesuai dengan anjurran dari pemerintah, masyarakat kita harusnya bangga mengenakan produk sepatu sepak bola asli Indonesia, selain dikarenakan kualitas yang didapat tidak kalah bahkan lebih baik dibanding produk sepatu sepak bola dari luar negeri, beberapa dari produk sepatu sepak bola Specs didesain menggunakan motif dari kebudayaan asli Indonesia, seperti songket, asmat, batik dan lain-lain. Hal ini secara tidak langsung membuat serta membuktikan bahwa Specs adalah produk yang cinta terhadap tanah air Indonesia dengan terus mengangkat nilai-nilai sosial serta budaya dan nilai leluhur yang ada di Indonesia. Setelah membeli produk sepatu sepak bola merek Specs, konsumen bisa membuktikan citra baik yang lama telah dibangun oleh perusahaan. Akhirnya konsumen diharapkan akan menjadi loyal kepada produk, dan akan melakukan pembelian kembali terhadap produk dari merek yang serupa di masa kemudian hari.

Konsumen ketika memutuskan untuk membeli suatu produk, konsumen lebih cenderung menggunakan dan melihat informasi dari orang yang sudah terlebih dahulu memakai produk tersebut. Memakai salah satu produk dikarenakan segi kualitas dari produk adalah salah satu yang merupakan 
pertimbangan dari konsumen dalam membelli produk yang kemudian akan digunakan serta bisa memberi manfaat sesuai keinginan setiap konsumen. Peran dari persepsi konsumen pada suatu produk adalah salah satu hal penting untuk memutuskan untuk membeli suatu produk. Persepsi merupakan salah satu elemen akan suatu pertimbangan saat memilih suatu produk (Grunert, 2005 dalam Shaharudin et al., 2011). Menurut Kotler dan Amstrong (2008:228) pemasaran persepsi jauh lebih penting dibanding realitas karena persepsi yang kemudian memberi pengaruh atas perilaku actual konsumen. Persepsi memberikan pengaruh bagaimana seseorang konsumen pada akhirnya memutuskan untuk memakai suatu produk maupun jasa yang ditawarkan dan dijual perusahaan. Persepsi dari kualitas produk itu sendiri membuat seseorang memiliki keinginan ataupun tidak dalam menggunakan suatu produk yang kemudian dapat memberikan suatu manfaat yang diharapkan dari konsumen tersebut. Bagi perusahaan, mengingkatkan kualitas produk adalah suatu perhatian yang utama dikarenakan kualitas merupakan komponen strategis dalam keunggulan kompetitif (Foster dan Sjoblom, 1996 dalam Ling et al., 2010).

Berdasarkan pada persepsi produk dari sepatu merek Specs. Specs merupakan sebuah perusahaan sepatu asal Indonesia yang menghasilkan berbagai macam perlengkapan olahraga. Specs menjadi pemimpin sepatu di pangsa pasar Indonesia. Specs juga menjadi sponsor sepatu bagi para pemain tim nasional Indonesia. Specs yang saat ini telah meraih sertifikat ISO-9001 dari Liyod Register Quality Asurance untuk Quality Management System pada tahun 1997 diposisikan sebagai perusahaan yang memproduksi sepatu olahraga dengan 
kualitas yang tinggi dengan manajemen yang berkualitas. Hal itu menambah kepercayaan masyarakat terhadap produk Specs. Specs meraih pasarnya di dalam kalangan remaja dan mahasiswa. Selain menjadi perusahaan sepatu pioneer di dalam negeri, Specs pun mengembangkan pasar hingga dapat menembus ke pasar di luar Indonesia.

Specs menghadapi persaingan ketat dengan brand-brand besar seperti Nike dan Adidas. Dengan mendunianya sepatu bola merek Nike dan Adidas, produsen sepatu Specs selalu berinovasi dan meningkatkan kreativitas untuk bersaing dengan produk pesaing dan menarik minat konsumen. Menjadi pioneer dalam pasar industri bukanlah sebuah jaminan, produsen sepatu Specs harus mencari cara-cara baru dalam mempertahankan pelanggan atau mencari pembeli-pembeli baru. Dalam meningkatkan kualitas pelayan konsumen, produsen Specs juga meningkatkan kemudahan dalam akses berbelanja terhadap niat beli konsumen, hal tersebut mempermudah produsen mengetahui seberapa banyak pengguna dan permintaan brand Specs di dalam persaingan produk dan jasa.

Pengalaman sebelumnya dari berbelanja online merupakan faktor yang penting dalam menentukan niat konsumen dalam membeli atau melakukan pembelian ulang suatu barang atau jasa secara online. Sehingga apabila pengalaman yang pernah dialami itu memberikan dampak baik bagi konsumen maka dapat dipastikan konsumen akan memutuskan berbelanja online berulang karena didasari oleh pengalaman baik yang didapat sebelumnya. Pengalaman adalah salah satu pertimbangan untuk memprediksi perilaku dikemudian hari. Konsumen menganggap bahwa dalam membeli tidak sekedar hanya memakai 
produk maupun jasa, tetapi juga dibutuhkan suatu pengalaman yang membuat terkesan (Prastyaningsih et al., 2014). Pengalaman kemudian didapat saat membeli produk serta jasa, juga merupakan salah satu dari faktor yang menjadi pertimbangan konsumen disaat memilih produk serta jasa yang diinginkan (Pramudita \& Japarianto, 2013). Pengalaman yang banyak, mengurangi kecenderungan dari konsumen dalam kekhawatiran terhadap resiko yang didapat saat melakukan belanja secara online (Kwon dan Noh, 2010).

Konsumen yang telah mengetahui persepsi produk dari Specs dan kemudahan konsumen dalam berbelanja, kemudahan akses informasi termasuk salah satu bagian dari bagaimana cara produsen dalam mengambil niat beli konsumen akan produk Specs yang kualitas bisa menyaingi brand-brand kompetitor saat ini. Akses informasi menurut (Wulandari dkk., 2007) adalah pencapaian informasi dengan menggunakan alat berupa telekomunikasi melalui saluran atau media. Akses informasi dapat dikatakan sebagai sebuah jembatan yang menghubungkan sumber informasi sehingga informasi yang dibutuhkan oleh setiap individu dapat terpenuhi. Akses informasi dapat ditemukan dimana saja, seperti di rumah, tempat kerja, sekolah, dan lain-lain. Seseorang mendapatkan informasi dari berbagai sumber misalnya dari koran, majalah, televisi, buku, guru, internet, dan orang yang berada disekitarnya.

Niat beli ulang mempengaruhi keinginan konsumen untuk menggunakan suatu produk seperti sepatu Specs. Niat beli merupakan keinginan dari konsumen terhadap suatu produk yang ada dari mereks tertentu. Niat beli diukur dengan mencari tahu tentang bagaimana kemungkinan dalam membeli suatu produk yang 
ada di iklan. Niat beli merupakan tahap dari kecenderungan seseorang dalam bertindak sebelum pada akhirnya melaksanakan pembelian barang (Martinez and Soyong Kim, 2012). Meskaran et al. (2013) menyatakan ada suatu perbedaan diantara pembelian aktual serta kecenderungan dalam pembelian. Membeli secara aktual diibaratkan pembelian yang sesungguhnya dilaksanakan oleh konsumen. Sedangkan kecenderungan pembelian adalah sebuah niat yang muncul pada konsumen guna melaksanakan pembelian dikemudian hari. Terdapat indikator dari niat beli yang dipakai oleh pelanggan dallam hal ini pencarian informasi mengenai kualitas produk, mengenai manfaat produk yang akan dibeli, memiliki kecenderungan terhadap produk tertentu, dan keinginan untuk segera membeli produk.

Penelitian sebelumnya mengenai pengaruh persepsi kualitas produk terhadap niat beli ulang telah banyak dilakukan. Penelitian Afif (2017) dan Arfiani (2015) menyimpulkan jika kualitas produk tidak mempengaruhi signifikan pada niat beli ulang. Kemudian hasil ini berbeda dari penelitian yang dilakukan oleh Pebriana (2016) dan (Astini, 2014) mengatakan jika kualitas produk mempengaruhi secara signifikan pada niat beli ulang. Penelitian sebelumnya mengenai pengalaman belanja online terhadap niat beli ulang telah dilakukan oleh Weisberg (2010) mengatakan jika pengalaman belanja online tidak mempengaruhi secara signifikan pada niat beli ulang. Hasil ini berbeda dan bertolak belakang dengan penelitian yang dilakukan (Huang et al., 2011) dan (Mohmed et al., 2013) yang menyatakan bahwa pengalaman belanja online berpengaruh positif terhadap niat beli ulang. Penelitian mengenai akses informasi terhadap niat beli ulang juga 
telah dilakukan oleh (Alhasanah et al., 2014) dengan kesimpulan bahwa akses informasi berpengaruh negatif dan signifikan terhadap niat beli ulang. Penelitian sebelumnya juga di dukung oleh penelitan (Wen et al., 2011) dan (Dutta et al., 2011) yang juga menyimpulkan bahwa akses informasi mempengaruhi secara positif dan signifikan pada niat beli ulang.

Tujuan Penelitian ini (1) Untuk memperjelas pengaruh dari persepsi kualitas produk terhadap niat beli ulang pada pembelian online sepatu sepak bola merek Specs di Kota Denpasar secara online. (2) Untuk menjelaskan pengaruh pengalaman belanja online terhadap niat beli ulang pada pembelian online sepatu sepak bola merek Specs di Kota Denpasar secara online. (3) Untuk menjelaskan pengaruh akses informasi trhadap niat beli ulang pada pembelian online sepatu sepak bola merek Specs di Kota Denpasar secara online.

Stevany (2014) kualitas produk adalah kemampuan suatu produk dalam menjalankan fungsinya, yang berupa daya tahan, keandalan, ketepatan, dan kemudahan penggunaan produk tersebut. Pengaruh persepsi konsumen terhadap kualitas akan membentuk persepsi kualitas terhadap suatu produk yang dapat menentukan nilai dari produk tersebut. Persepsi kualitas merupakan persepsi konsumen, maka dapat diramalkan jika persepsi pelanggan negatif, produk tidak akan disukai dan tidak bertahan lama di pasar. Sebaliknya, jika persepsi kualitas positif maka produk akan disukai dan akan nada pembelian ulang yang dilakukan oleh konsumen.

Menurut Durianto (2004) hanya produk yang memiliki persepsi kualitas kuat yang mampu bersaing, merebut dan menguasai pasar. Persepsi kualitas 
adalah persepsi pelanggan terhadap keseluruhan kualitas atau keunggulan suatu produk atau jasa layanan berkaitan dengan apa yang diharapkan oleh pelanggan. Sudah selayaknya produk-produk baru bersaing dengan kondisi pasar dengan upaya peningkatan perceived quality sehingga kebutuhan dan keinginan konsumen dapat terpenuhi dan terpuaskan sehingga konsumen menjadi loyal dalam melakukan pembelian ulang suatu produk.

Menurut penelitian yang dilaksanakan oleh Suprapti (2010) mengungkapkan bahwa persepsi kualitas produk mempengaruhi secara positif terhadap niat beli ulang. Begitu juga penelitian dari Durianto (2004) membuktikan bahwa persepsi kualitas memiliki hubungan signifikan terhadap niat beli ulang. Sesuai dengan penjelasan di atas jadi hipotesis yang akan dibuat adalah:

$\mathrm{H}_{1}$ : Persepsi kualitas produk berpengaruh positif dan signifikan terhadap niat beli ulang.

Shim dan Drake (dalam Ling, 2010) memiliki pendapat jika konsumen yang mempunyai niat berbelanja secara online yang kuat di situs belanja online yang tersedia biasanya telah mempunyai pengalaman dalam pembelian sebelumnya sehingga membantu utk mengurangi rasa kekahwatirannya. Sehingga konsumen akan membeli produk tersebut secara online stelah mempunyai pengalaman. Konsumen biasanya mendapatkan pengalaman dengan cara melakukan pembelian kecil awalnya, dan kemudian mereka akan akan lebih memberanikan diri dalam berbelanja online (Seckler dalam Ling, 2010).

Pengalaman belanja online yang dilakukan oleh para pelanggan akan memberikan dampak bagi para pelanggan dikemudian hari. Apabila pengalaman belanja online yang dilakukan sebelumnya tidak baik, maka para pelanggan 
cenderung tidak akan mempunyai niat untuk berbelanja kembali, akan tetapi sebaliknya jika pengalaman belanja online sebelumnya baik maka para pelanggan cenderung akan mempunyai minat untuk melakukan pembelian ulang. Pengalaman membeli sebelumnya secara online berpengaruh positif dan signifikan dengan niat membeli kembali secara online (Mohmed et al., 2013).

Menurut penelitian yang dilakukan Huang et al., (2011) menyatakan bahwa Pengalaman dari pelanggan dalam berbelanja secara online mempengaruhi secara positif terhadap niat pembelian kembali. Jadi, berdasarkan penelitian diatas, maka kesimpulan hipotesis adalah sebagai berikut:

$\mathrm{H}_{2}$ : Pengalaman belanja online berpengaruh positif dan signifikan terhadap niat beli ulang.

Hubungan dari intensitas dipergunakannya internet guna mencari informasi dan intensitas diperggunakannya internet guna berbelanja telah didapatkan di model online pre-purchase intentions yang dikemukakan (Shim et al., 2001). Setiap individu yang mempunyai intesitas lebih besar saat mempergunakan internet dalam mencari inforrmasi akan mempunyai intensitas lebih besar disaat berbelanja mempergunakan internet. Klein's (1998) menyampaikan pendapatnya jika konsumen akan memilih cara paling murah dalam melaksanakan pencarian dan berbelanja produk serta jasa. Pengalam empiris yang ada dilapangan mendukung bukti jika konsumen lebih menyukai utk mendapat informasi melalui perantara internet disaat berbelanja suatu produk scr online (Kim and Park, 2005). Org yang pernah berbelanja online mengungkapkan jika mereka dapat lebih dahulu mengetes berbagai macam pilihan dari produk tersebut melalui perbelanjaan secara online dibandingkan secara offline atau langsung 
(Wolfinbarger and Gilly, 2000). Konsumen bukan hanya melihat perbandingan dari harga melainkan juga melihat perbandingan dari atribut produk yang ditawarkan oleh toko eceran online atau membandingkannya dengan toko retail online lain yang tersedia.

Menurut penelitian yang telah dilakukan oleh Kristono (2010) menyatakan bahwa perolehan informasi dengan kualitas yang baik dapat meningkatkan minat beli ulang dan membuat pelanggan merasa puas dalam berbelanja di toko online. Menurut penelitian yang dilakukan oleh Rizki, dkk. (2015) menunjukan bahwa variabel akses informasi berpengaruh positif terhadap minat beli ulang. Jadi, berdasarkan penelitian diatas, maka kesimpulan hipotesis sebagai berikut:

$\mathrm{H}_{3}$ : Akses informasi berpengaruh positif dan signifikan terhadap niat beli ulang.

Kerangka konseptual didasarkan pada hipotesis diusulkan dengan Gambar 1.

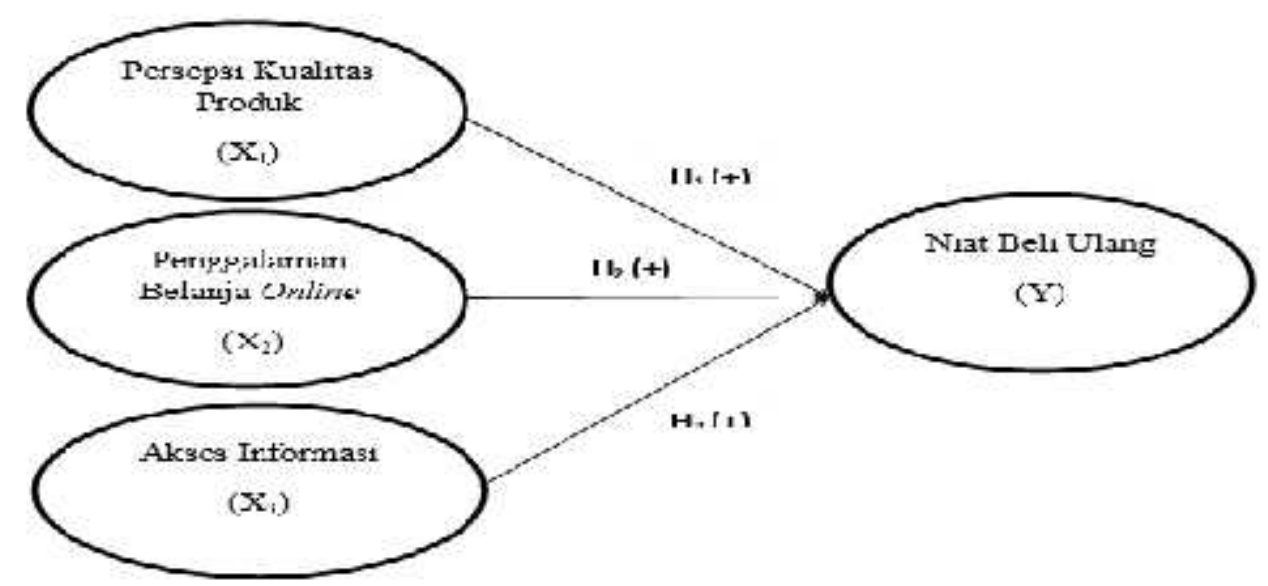

\section{Gambar 1. Kerangka Konsep}

\section{METODE PENELITIAN}

Desain dari penelitian ini memakai pendekatan kuantitatif yang mempunyai sifat asosiatif. Penelitian mempunyai lokasi di kota Denpasar. Subjek dari 
penelitian ini adalah konsumen yang menggunakan sepatu sepak bola merek Specs di Kota Denpasar. Objek dalam penelitian ini adalah pengaruh persepsi kualitas produk, pengalaman belanja online, dan akses informasi terhadap niat beli ulang pembelian sepatu sepak bola merek Specs di Kota Denpasar.

Tabel 2.

Indikator Variabel Penelitian

\begin{tabular}{|c|c|c|}
\hline No & Variabel & Indikator \\
\hline 1 & $\begin{array}{l}\text { Persepsi Kualitas } \\
\text { Produk (X1) }\end{array}$ & $\begin{array}{l}\text { 1) Konsistensi } \\
\text { 2) Kehandalan } \\
\text { 3) Keunggulan }\end{array}$ \\
\hline 2 & $\begin{array}{l}\text { Pengalaman belanja } \\
\text { online }(\mathrm{X} 2)\end{array}$ & $\begin{array}{l}\text { 1) Puas dengan pengalaman berbelanja online sebelumnya } \\
\text { 2) Senang dengan pengalaman berbelanja online sebelumnya } \\
\text { 3) Berbagi pengalaman berbelanja di situs jual beli online } \\
\text { dengan teman }\end{array}$ \\
\hline 3 & Akses informasi (X3) & $\begin{array}{l}\text { 1) Informasi yang tepat waktu } \\
\text { 2) Informasi yang relevan } \\
\text { 3) Informasi yang dapat dipercaya }\end{array}$ \\
\hline 4 & Niat Beli (Y) & $\begin{array}{l}\text { 1) Adanya kesempatan } \\
\text { 2) Adanya kemungkinan } \\
\text { 3) Adanya Niat }\end{array}$ \\
\hline
\end{tabular}

Sumber : Hasil pengolahan data primer, 2018

Populasi dalam penelitian ini adalah masyarakat yang berniat dan melakukan pembelian ulang sepatu sepak bola merek Specs di Kota Denpasar. Metode dari penentuan sampel yang dipakai adalah non-probability sampling. Dalam penelitian ini menggunakan sampel sejumlah 100 orang yang didapatkan dari jumlah variabel sebanyak 12 kemudian dikalikan 8 mendapatkan hasil 96 yang dibulatkan menjadi 100. Dalam mencari data, dipergunakan beberapa teknik dari pengumpulan data yang ada yaitu kuesioner, observasi dan wawancara. Data dalam penelitian ini dikumpulkan melalui instrumen penelitian berupa kuesioner.

Uji validitas dipakai untuk menguji valid atau tidaknya suatu instrument penelitian, jika ada kesamaan diantara data yang sudah terkumpul serta data yang sesungguhnya terjadi di objek penelitian. Ketentuan dari suatu instrument 
dinyatakan valid atau sah jika mempnuyai koefisien korelasi Pearson Product Moment (r) > 0,3 serta alpha sebesar 0,05 (Sugiyono, 2013:182). Mengingat sumber data yang dipakai dalam penelitian yaitu penarikan data primer yang kemudian mempergunakan kuesioner, sehingga data yang didapat adalah memiliki sifat kualitatif yang kemudian sulit dalam perhitungan. Sehingga diperlukannya suatu cara agar bisa mengkuantitatifkan data itu dengan memberi skor di masing masing jawaban dari responden. Skala Likert dipakai untuk mengukur pendapat, sikap serta persepsi seseorang ataupun sekelompok orang mengenai fenomena sosial (Sugiyono, 2013:86).

Analisis regresi berganda dipakai dalam menganalisiss suatu variabel dependen dan dipengaruhi lebih dari sebuah variabel independen. Dipergunakan program SPSS untuk menganalisis data. Model dari regresi linear berganda diperlihatkan dalam persamaan dibawah, yaitu:

$Y=\alpha+\beta_{1} X_{1}+\beta_{2} X_{2}+\beta_{3} X_{3}+\varepsilon$

Keterangan:

$\mathrm{Y}=$ Niat beli ulang

$\mathrm{X}_{1} \quad=$ Persepsi kualitas produk

$\mathrm{X}_{2} \quad=$ pengalaman belanja online

$\mathrm{X}_{3} \quad=$ Akses informasi

$\alpha \quad=$ Konstanta

$\beta_{1} \beta_{2} \beta_{3}=$ Koefisien regresi

$\varepsilon \quad=$ Komponen residual

Terlebih dahulu melaksanakan uji asumsi klasik, sebelum melakukan teknik analisis regresi linier berganda. Jenis - jenis uji asumsi klasik yang dipakai adalah Uji Normalitas, Uji Multikolinearitas, Uji Heterokedastisitas. Koefisien 
determinasi $\left(\mathrm{R}^{2}\right)$ pada intinya mengukur seberapa jauh kemampuan model untuk menerangkan variasi variabel dependen.

Uji F bertujuan guna menguji apakah keseluruhan variabel independen yang dimasukkan ke dalam model secara simultan atau bersama-sama mempunyai pengaruh pada variabel dependen (Ghozali, 2006). Uji statistik t dipergunakan untuk mengetahui seberapa jauh masing-masing variabel independen.

\section{HASIL DAN PEMBAHASAN}

Data dari responden yang dipakai dalam penelitian ini memiliki jumlah 100 responden yang meliputi tiga aspek dalam karakteristik adalah jenis kelamin, pengalaman penggunaan belanja online, usia. Distribusi responden berdasarkan usia menunjukkan bahwa responden yang berusia kurang dari 25 tahun sebanyak 39 orang, responden yang berusia 25 sampai 35 tahun sebanyak 36 orang dan responden yang berusia lebih dari 35 sampai 45 tahun sebanyak 25 orang. Hal ini menunjukkan bahwa dalam penelitian ini lebih banyak responden yang berusia kurang dari 25 tahun yang melakukan pembelian ulang sepatu sepak bola merek Specs di Kota Denpasar. Distribusi responden berdasarkan pengalaman penggunaan belanja online menunjukkan bahwa responden yang memiliki pengalaman belanja online kurang dari 1 tahun sebanyak 10 orang, yang memiliki pengalaman belanja online selama 1 sampai 2 tahun sebanyak 32 orang, yang memiliki pengalaman belanja online selama lebih dari 2 tahun sampai 3 tahun sebanyak 37 orang, dan yang memiliki pengalaman belanja online lebih dari 3 tahun sebanyak 21 orang. Hal ini menunjukkan bahwa dalam penelitian ini lebih banyak responden yang memiliki pengalaman belanja online selama lebih dari 2 
tahun sampai 3 tahun. Hal tersebut memberikan informasi bahwa konsumen yang melakukan pembelian ulang sepatu sepak bola merek Specs di Kota Denpasar dalam penelitian ini memiliki pengalaman belanja online yang cukup tinggi.

Tabel 3.

Rekapitulasi Hasil Uji Validitas Instrumen Penelitian

\begin{tabular}{cccc}
\hline Variabel & Indikator & Koefisien Korelasi & Keterangan \\
\hline & $\mathrm{X}_{1.1}$ & 0,757 & Valid \\
Persepsi kualitas & $\mathrm{X}_{1.2}$ & 0,732 & Valid \\
produk $\left(\mathrm{X}_{1}\right)$ & $\mathrm{X}_{1.3}$ & 0,532 & Valid \\
& $\mathrm{X}_{1.4}$ & 0,577 & Valid \\
& $\mathrm{X}_{1.5}$ & 0,791 & Valid \\
Pengalaman belanja & $\mathrm{X}_{2.1}$ & 0,809 & Valid \\
online $\left(\mathrm{X}_{2}\right)$ & $\mathrm{X}_{2.2}$ & 0,819 & Valid \\
& $\mathrm{X}_{2.3}$ & 0,801 & Valid \\
Akses informasi $\left(\mathrm{X}_{3}\right)$ & $\mathrm{X}_{3.1}$ & 0,832 & Valid \\
& $\mathrm{X}_{3.2}$ & 0,901 & Valid \\
Niat beli ulang & $\mathrm{X}_{3.3}$ & 0,887 & Valid \\
$(\mathrm{Y})$ & $\mathrm{Y}_{1}$ & 0,816 & Valid \\
& $\mathrm{Y}_{2}$ & 0,860 & Valid \\
\hline
\end{tabular}

Sumber : Hasil pengolahan data primer, 2018

Hasil dari uji validitas ditunjukan pada Tabel 3. dapat dilihat jika keseluruhan variabel mempunyai nilai koefisien korelasi yang mempunyai skor total dari seluruh item pernyataan lebih besar dari 0,30 . Hal tersebut menunjukkan jika butir-butir dari pernyataan didalam instrumen penelitian tersebut adalah valid, sehingga bisa dipergunakan untuk melaksanakan penelitian.

Tabel 4.

Rekapitulasi Hasil Uji Reliabilitas Instrumen Penelitian

\begin{tabular}{clcc}
\hline No. & \multicolumn{1}{c}{ Variabel } & Cronbach'sAlpha & Keterangan \\
\hline 1 & Persepsi kualitas produk $\left(\mathrm{X}_{1}\right)$ & 0,769 & Reliabel \\
2 & Pengalaman belanja online $\left(\mathrm{X}_{2}\right)$ & 0,830 & Reliabel \\
3 & Akses informasi $\left(\mathrm{X}_{3}\right)$ & 0,854 & Reliabel \\
4 & Niat beli ulang $(\mathrm{Y})$ & 0,847 & Reliabel \\
\hline
\end{tabular}

Sumber : Hasil pengolahan data primer, 2018 
Hasil dari uji reliabilitas dilihat dalam Tabel 4. memperlihatkan jika keseluruhan instrumen penelitian mempunyai koefisien Cronbach's Alpha lebih besar dari 0,60. Sehingga bisa dikatakan jika keseluruhan variabel sudah memenuhi syarat dari reliabilitas atau kehandalan sehingga bisa dipergunakan untuk melaksanakan penelitian.

Tabel 5.

Kriteria Pengukuran Deskripsi Variabel Penelitian

\begin{tabular}{ccc}
\hline No. & Skala Pengukuran & Kriteria \\
\hline 1 & $1,00-1,80$ & Sangat Rendah \\
2 & $1,81-2,60$ & Rendah \\
3 & $2,61-3,40$ & Sedang \\
4 & $3,41-4,20$ & Tinggi \\
5 & $4,21-5,00$ & Sangat Tinggi \\
\hline
\end{tabular}

Sumber : Hasil pengolahan data primer, 2018

Keseluruhan dari nilai rata-rata dari jawaban responden pada variabel persepsi kualitas produk mempunyai nilai sebesar 3,75. Hal ini berarti bahwa konsumen di Kota Denpasar sudah memiliki persepsi kualitas produk yang tinggi terhadap sepatu sepak bola merek Specs. Nilai rata-rata jawaban responden terendah terhadap variabel persepsi kualitas produk terdapat pada pernyataan "Saya merasa sepatu dengan merek Specs memberikan kenyamanan pada saat digunakan", mempunyai nilai rata-rata 3,55. Ini memperlihatkan jika masih ada beberapa konsumen yang merasa kurang nyaman saat menggunakan Sepatu sepak bola merek Specs. Untuk lebih lengkapnya, disajikan pada tabel 6. berikut. 
Tabel 6.

Deskripsi Jawaban Responden Terhadap Variabel Persepsi kualitas produk

\begin{tabular}{|c|c|c|c|c|c|c|c|c|}
\hline \multirow{2}{*}{ No } & \multirow{2}{*}{ Pernyataan } & \multicolumn{5}{|c|}{ Frekuensi Jawaban Responden } & \multirow{2}{*}{$\begin{array}{l}\text { Rata- } \\
\text { Rata }\end{array}$} & \multirow[t]{2}{*}{ Kriteria } \\
\hline & & STS & TS & $\mathbf{N}$ & $\mathbf{S}$ & SS & & \\
\hline 1 & $\begin{array}{l}\text { Sepatu merek Specs sesuai } \\
\text { dengan kualitas yang } \\
\text { ditawarkan }\end{array}$ & 0 & 12 & 20 & 37 & 32 & 3,87 & Tinggi \\
\hline 2 & $\begin{array}{l}\text { Sepatu merek Specs lebih tahan } \\
\text { lama }\end{array}$ & 1 & 11 & 23 & 43 & 22 & 3,74 & Tinggi \\
\hline 3 & $\begin{array}{l}\text { Saya merasa sepatu dengan } \\
\text { merek Specs memberikan } \\
\text { kenyamanan pada saat } \\
\text { digunakan }\end{array}$ & 0 & 3 & 44 & 48 & 5 & 3,55 & Tinggi \\
\hline 4 & $\begin{array}{l}\text { Saya merasa tampilan produk } \\
\text { Specs lebih menarik perhatian }\end{array}$ & 1 & 6 & 33 & 38 & 22 & 3,74 & Tinggi \\
\hline 5 & $\begin{array}{l}\text { Kualitas produk Specs sesuai } \\
\text { dengan harga yang ditawarkan }\end{array}$ & 0 & 5 & 21 & 56 & 18 & 3,87 & Tinggi \\
\hline & Rata-rata keseluruhan varia & Pers & si ku & ta & du & & 3,75 & Tinggi \\
\hline
\end{tabular}

Sumber : Hasil pengolahan data primer, 2018

Tabel 7.

Deskripsi Jawaban Responden Pada Variabel Pengalaman belanja online

\begin{tabular}{|c|c|c|c|c|c|c|c|c|}
\hline \multirow{2}{*}{ No } & \multirow{2}{*}{ Pernyataan } & \multicolumn{5}{|c|}{ Frekuensi Jawaban Responden } & \multirow{2}{*}{$\begin{array}{l}\text { Rata- } \\
\text { Rata }\end{array}$} & \multirow{2}{*}{ Kriteria } \\
\hline & & STS & TS & $\mathbf{N}$ & $\mathbf{S}$ & SS & & \\
\hline 1 & $\begin{array}{l}\text { Saya merasa puas terhadap } \\
\text { produk sepatu Specs yang saya } \\
\text { beli dengan belanja online }\end{array}$ & 0 & 2 & 26 & 50 & 22 & 3,92 & Tinggi \\
\hline 2 & $\begin{array}{l}\text { Saya merasa senang dengan } \\
\text { belanja online produk sepatu } \\
\text { merek Specs }\end{array}$ & 0 & 2 & 14 & 62 & 22 & 4,04 & Tinggi \\
\hline 3 & $\begin{array}{l}\text { Saya melakukan pembelian } \\
\text { ulang produk sepatu merek } \\
\text { Specs serta membagikan } \\
\text { pengalaman kepada orang- } \\
\text { orang disekitar }\end{array}$ & 0 & 1 & 17 & 48 & 34 & 4,15 & Tinggi \\
\hline & Rata-rata keseluruhan variab & Peng: & na & & & & 4,04 & Tinggi \\
\hline
\end{tabular}

Sumber : Hasil pengolahan data primer, 2018

Tabel 7. diatas memperlihatkan secara keseluruhan nilai rata-rata jawaban responden terhadap variabel pengalaman belanja online memiliki nilai sebesar 4,04. Hal ini berarti jika konsumen di Kota Denpasar sudah memiliki pengalaman belanja online yang tinggi terhadap sepatu sepak bola merek Specs. Nilai rata-rata jawaban responden terendah terhadap variabel pengalaman belanja online terdapat 
pada pernyataan "Saya merasa puas terhadap produk sepatu Specs yang saya beli dengan belanja online", mempunyai nilai rata-rata sebesar 3,92. Hal ini memperlihatkan jikalau masih ada beberapa konsumen yang merasa kurang puas terhadap produk sepatu Specs pada saat membelinya secara online.

Tabel 8.

Deskripsi Jawaban Responden Terhadap Variabel Akses informasi

\begin{tabular}{|c|c|c|c|c|c|c|c|c|}
\hline \multirow{2}{*}{ No } & \multirow{2}{*}{ Pernyataan } & \multicolumn{5}{|c|}{ Frekuensi Jawaban Responden } & \multirow{2}{*}{$\begin{array}{l}\text { Rata- } \\
\text { Rata }\end{array}$} & \multirow{2}{*}{ Kriteria } \\
\hline & & STS & TS & $\mathbf{N}$ & $\mathbf{S}$ & SS & & \\
\hline 1 & $\begin{array}{l}\text { Akses informasi yang } \\
\text { diberikan oleh situs belanja } \\
\text { online tepat waktu dan selalu } \\
\text { update. }\end{array}$ & 0 & 7 & 55 & 31 & 7 & 3,38 & Sedang \\
\hline 2 & $\begin{array}{l}\text { Akses informasi yang } \\
\text { diberikan oleh situs belanja } \\
\text { online relevan dengan yang } \\
\text { dibutuhkan konsumen. }\end{array}$ & 0 & 4 & 45 & 33 & 18 & 3,65 & Tinggi \\
\hline 3 & $\begin{array}{l}\text { Akses informasi yang } \\
\text { diberikan oleh situs belanja } \\
\text { online dapat dipercaya dalam } \\
\text { penjualan online }\end{array}$ & 0 & 9 & 47 & 30 & 14 & 3,49 & Tinggi \\
\hline & Rata-rata keseluruhan v & riabel & zses i & 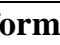 & & & 3,51 & Tinggi \\
\hline
\end{tabular}

Sumber : Hasil pengolahan data primer, 2018

Tabel 8. memperlihatkan keseluruhan dari nilai rata-rata jawaban dari responden pada variabel akses informasi mempunyai nilai sebesar 3,51. Hal ini berarti jika konsumen di Kota Denpasar sudah meperoleh akses informasi yang tinggi terhadap sepatu sepak bola merek Specs. Nilai rata-rata jawaban responden terendah terhadap variabel akses informasi terdapat pada pernyataan "Akses informasi yang diberikan oleh situs belanja online tepat waktu dan selalu update", mempunyai nilai rata-rata sebesar 3,38. Hal ini memperlihatkan jika masih ada konsumen yang merasa jika akses informasi yang diberikan oleh situs belanja online sepatu sepak bola merek Specs tidak tepat waktu dan kurang update, sehingga membuat konsumen kurang tertarik melakukan pembelian ulang. 
Tabel 9.

Deskripsi Jawaban Responden Terhadap Variabel Niat Beli Ulang

\begin{tabular}{|c|c|c|c|c|c|c|c|c|}
\hline \multirow{2}{*}{ No } & \multirow{2}{*}{ Pernyataan } & \multicolumn{5}{|c|}{ Frekuensi Jawaban Responden } & \multirow{2}{*}{$\begin{array}{l}\text { Rata- } \\
\text { Rata }\end{array}$} & \multirow{2}{*}{ Kriteria } \\
\hline & & STS & TS & $\mathbf{N}$ & $\mathbf{S}$ & SS & & \\
\hline 1 & $\begin{array}{l}\text { Saya ingin berulang kali } \\
\text { menggunakan situs belanja } \\
\text { online untuk memesan produk } \\
\text { sepatu sepak bola merek Specs }\end{array}$ & 0 & 1 & 10 & 46 & 43 & 4,31 & Tinggi \\
\hline 2 & $\begin{array}{l}\text { Kemungkinan besar saya akan } \\
\text { kembali memesan produk } \\
\text { sepatu sepak bola merek Specs } \\
\text { melalui situs belanja online di } \\
\text { masa depan }\end{array}$ & 0 & 1 & 15 & 59 & 25 & 4,08 & Tinggi \\
\hline 3 & $\begin{array}{l}\text { Saya berniat untuk memesan } \\
\text { kembali produk sepatu sepak } \\
\text { bola merek Specs melalui situs } \\
\text { belanja online di masa depan }\end{array}$ & 0 & 2 & 18 & 59 & 21 & 3,99 & Tinggi \\
\hline & Rata-rata keseluruhan & riabel & iat b & ula & & & 4,13 & Tinggi \\
\hline
\end{tabular}

Sumber : Hasil pengolahan data primer, 2018

Tabel 9. menunjukkan keseluruhan dari nilai rata-rata jawaban responden terhadap variabel niat beli ulang memiliki nilai sebesar 4,13. Ini berarti jika konsumen di Kota Denpasar sudah memiliki niat beli ulang yang tinggi terhadap sepatu sepak bola merek Specs. Nilai rata-rata jawaban responden terendah terhadap variabel niat beli ulang terdapat pada pernyataan "Saya berniat untuk memesan kembali produk sepatu sepak bola merek Specs melalui situs belanja online di masa depan", dengan hasil dari nilai rata-rata sebesar 3,99. Hal ini menunjukan masih ada konsumen yang kurang berniat untuk memesan kembali produk sepatu sepak bola merek Specs melalui situs belanja online di masa depan.

Tabel 10.

Hasil Uji Normalitas

\begin{tabular}{cc}
\hline & Unstandardized Residual \\
\hline $\mathrm{N}$ & 100 \\
Kolmogorov-Smirnov $Z$ & 0,618 \\
Asymp.Sig.(2-tailed) & 0,840 \\
\hline
\end{tabular}

Sumber : Hasil pengolahan data primer, 2018

Berdasarkan dari Tabel 10. memperlihatkan jika nilai dari Kolmogorov

Smirnov sebesar 0,618, kemudian nilai dari Asymp. Sig. (2-tailed) sebesar 0,840. 
Hal itu mengindikasikan jika model dari persamaan regresi itu mempunyai distribusi yang normal dikarenakan nilai dari Asymp. Sig. (2-tailed) 0,840 melebihi nilai alpha yaitu 0,05 .

Tabel 11.

Hasil Uji Multikoleniaritas

\begin{tabular}{lcc}
\multicolumn{1}{c}{ Variabel } & Tolerance & VIF \\
\hline Persepsi kualitas produk $\left(\mathrm{X}_{1}\right)$ & 0,884 & 1,131 \\
Pengalaman belanja online $\left(\mathrm{X}_{2}\right)$ & 0,838 & 1,194 \\
Akses informasi $\left(\mathrm{X}_{3}\right)$ & 0,847 & 1,180 \\
\hline
\end{tabular}

Sumber : Hasil pengolahan data primer, 2018

Berdasarkan dari Tabel 11. diperlihatkan jika nilai tolerance dan VIF dari keseluruhan variabel telah memperlihatkan yaitu nilai tolerance dari kesetiap variabel melebihi dari 10\% dan kemudian nilai dari VIF lebih kecil dari 10\% yang mempunyai arti jika model persamaan dari regresi bebas multikolinearitas.

Tabel 12.

Hasil Uji Heteroskedastisitas

\begin{tabular}{|c|c|c|c|c|c|}
\hline \multirow[t]{2}{*}{ Model } & \multicolumn{2}{|c|}{$\begin{array}{c}\text { Unstandardized } \\
\text { Coefficients }\end{array}$} & \multirow{2}{*}{$\begin{array}{c}\begin{array}{c}\text { Standardized } \\
\text { Coefficients }\end{array} \\
\text { Beta } \\
\end{array}$} & \multirow[b]{2}{*}{$\mathrm{T}$} & \multirow[b]{2}{*}{ Sig. } \\
\hline & $\mathrm{B}$ & Std. Error & & & \\
\hline 1 (Constant) & 1.560 & .519 & & 3.004 & .003 \\
\hline Persepsi Kualitas Produk & -.006 & .022 & -.028 & -.259 & .796 \\
\hline Pengalaman Belanja Online & -.030 & .038 & -.086 & -.786 & .434 \\
\hline Akses Informasi & -.037 & .031 & -.127 & -1.170 & .245 \\
\hline
\end{tabular}

Sumber : Hasil pengolahan data primer, 2018

Pada Tabel 12. memperlihatkan jika nilai Signifikansi pada variabel persepsi kualitas produk, pengalaman belanja online dan akses informasi, masingmasing memiliki nilai 0,$796 ; 0,434$ dan 0,245 . Nilai itu lebih besar atau melebihi dari 0,05 yang diartikan jika tidak terdapatnya pengaruh antara variabel bebas terhadap absolute residual. Sehingga, model yang dibangun tidak terdapat gejala dari heteroskedastisitas. 
Tabel 13.

Hasil Analisis Regresi Linier Berganda

\begin{tabular}{llrrrrr}
\hline Model & \multicolumn{2}{c}{$\begin{array}{c}\text { Unstandardized } \\
\text { Coefficients }\end{array}$} & \multicolumn{2}{c}{$\begin{array}{c}\text { Standardized } \\
\text { Coefficients }\end{array}$} & & \\
\cline { 2 - 5 } & \multicolumn{1}{c}{$\mathrm{B}$} & \multicolumn{1}{c}{ Std. Error } & Beta & \multicolumn{1}{c}{ T } & \multicolumn{1}{c}{ Sig. } \\
\hline 1 (Constant) & -.137 & .824 & & -.166 & .868 \\
& Persepsi kualitas produk & .287 & .035 & .482 & 8.275 & .000 \\
Pengalaman belanja online & .394 & .060 & .392 & 6.558 & .000 \\
Akses informasi & .224 & .049 & .270 & 4.533 & .000 \\
\hline
\end{tabular}

Sumber : Hasil pengolahan data primer, 2018

Berdasarkan Tabel 13. diperlihatkan jika hasil dari analisis regresi linear berganda, memiliki persamaan struktural adalah sebagai berikut ini :

$$
\mathrm{Y}=-0,137+0,287 \mathrm{X} 1+0,394 \mathrm{X} 2+0,224 \mathrm{X} 3+\mathrm{e}
$$

Nilai dari koefisien regresi dari masing - masing variabel bebas yang ada mempunyai nilai positif serta mempunyai nilai dari signifikansi uji t kurang dari 0,05. Hal ini memperlihatkan jika keseluruhan variabel bebas mempunyai pengaruh positif serta signifikan terhadap variabel.

\section{Tabel 14.}

\section{Hasil Uji Koefisien Determinasi}

\begin{tabular}{ccccc}
\hline Model & $\mathrm{R}$ & $\mathrm{R}$ Square & Adjusted R Square & $\begin{array}{c}\text { Std. Error of the } \\
\text { Estimate }\end{array}$ \\
\hline 1 & $.844^{\mathrm{a}}$ & .712 & .703 & .948 \\
\hline
\end{tabular}

Sumber : Hasil pengolahan data primer, 2018

Nilai determinasi dalam Tabel 14. menunjukkan nilai R Square sebesar 0,703. Hal ini mempunyai arti jika sebesar 70,3\% variasi niat beli ulang dipengaruhi variasi persepsi kualitas produk, pengalaman belanja online, dan akses informasi kemudian sisa sebesar 29,7\% dijelaskan oleh faktor lainnya yang tidak masuk ke dalam model.

Tabel 15.

Uji Anova

\begin{tabular}{llrrrrr}
\hline Model & & Sum of Squares & df & Mean Square & F & Sig. \\
\hline 1 & Regression & 213.301 & 3 & 71.100 & 79.129 & $.000^{\mathrm{a}}$ \\
& Residual & 86.259 & 96 & .899 & & \\
& Total & 299.560 & 99 & & & \\
\hline
\end{tabular}

Sumber : Hasil pengolahan data primer, 2018 
Tabel 15. memperlihatkan hasil dari uji anova (Uji F), kemudian didapatkan nilai dari kelompok pembanding $=3$, kemudian nilai dalam kelompok penyebut $=$ 96, pada alfa $=0,05$ maka nilai $F$ tabelnya adalah $F 0,05(3,96)=2,70$. Sedang $F$ hitung $=79,129$. Nilai Fhitung $>$ Ftabel, 79,129>2,70, dengan nilai atas signifikansi $0,000<0,05$. Maka H0 ditolak dengan taraf nyata 0,05 (H1 diterima). Kemudian kesimpulan yang didapat, pada kelompok yang diuji mempunyai perbedaan yang nyata (signifikan) berarti jika persepsi kualitas produk, pengalaman belanja online dan akses informasi secara simultan berpengaruh secara signifikan terhadap niat beli ulang.

Kriteria dari pengujian dalam menjelaskann interpretasi dari pengaruh antara masing-masing variabel ialah jika nilai dari signifikansi $<0,05$ maka $\mathrm{H}_{0}$ ditolak dan $\mathrm{H}_{1}$ diterima. Kebalikannya, jika nilai signifikansi > 0,05 maka $\mathrm{H}_{0}$ diterima dan $\mathrm{H}_{1}$ ditolak.

1) Pengaruh persepsi kualitas produk terhadap niat beli ulang

Berdasarkan hasil dari analisis pengaruh persepsi kualitas produk terhadap niat beli ulang didapatkan nilai signifikansi sebesar 0,000 dengan nilai koefisien regresi 0,287. Nilai Signifikansi $0,000<0,05$ mengindikasikan jika $\mathrm{H}_{0}$ ditolak dan $\mathrm{H}_{1}$ diterima. Yang kemudian memiliki arti jika persepsi kualitas produk berpengaruh secara positif dan signifikan terhadap niat beli ulang.

2) Pengaruh pengalaman belanja online terhadap niat beli ulang.

Berdasarkan hasil dari analisis pengaruh pengalaman belanja online terhadap niat beli ulang diperoleh nilai signifikansi sebesar 0,000 dengan nilai koefisien regresi 0,394 . Nilai Signifikansi $0,000<0,05$ mengindikasikan jika $\mathrm{H}_{0}$ 
ditolak dan $\mathrm{H}_{2}$ diterima. Yang kemudian memiliki arti jika pengalaman belanja online berpengaruh secara positif dan signifikan terhadap niat beli ulang.

3) Pengaruh akses informasi terhadap niat beli ulang.

Berdasarkan hasil dari analisis pengaruh akses informasi terhadap niat beli ulang diperoleh nilai signifikansi sebesar 0,000 dengan nilai koefisien regresi 0,234. Nilai Signifikansi $0,000<0,05$ mengindikasikan jika $\mathrm{H}_{0}$ ditolak dan $\mathrm{H}_{3}$ diterima. Hasil ini memiliki arti jika akses informasi berpengaruh positif dan signifikan terhadap niat beli ulang.

Implikasi dari hasil penelitian memiliki cakupan dua hal, yaitu implikasi teoritis dimana penelitian yang dilaksanakan bisa memberikan kontribusi mengenai pengaruh persepsi kualitas produk, pengalaman belanja online, dan akses informasi terhadap niat beli ulang pada pembelian online sepatu sepak bola merek Specs di Kota Denpasar. Hasil dari uji hipotesis dalam penelitian ini ditemukan jika keseluruhan variabel bebas yang terdiri dari persepsi kualitas produk $\left(\mathrm{X}_{1}\right)$, pengalaman belanja online $\left(\mathrm{X}_{2}\right)$, dan akses informasi $\left(\mathrm{X}_{3}\right)$, secara statistik berpengaruh positif pada niat beli ulang secara online sepatu sepak bola merek Specs di Kota Denpasar, sehingga variabel - variabel itu bisa dipertahankan sebagai variabel bebas untuk penelitian dikemudian hari. Sedangkan implikasi praktis dimana penelitian ini memberi implikasi bagi pihak marketing Sepatu Sepak Bola merek Specs sebagai bahan pertimbangan dan evaluasi mengenai niat beli ulang konsumen serta faktor-faktor yang memengaruhinya. Pihak marketing Sepatu Sepak Bola merek Specs di kota Denpasar dalam meningkatkan niat beli ulang konsumen sebaiknya meningkatkan 
kenyamanan pada saat mengggunakan produk specs, meningkatkan pelayanan penjualan sepatu specs dan selalu memperbaharui informasi update didalam situs belanja sepatu merek specs. Sehingga konsumen berniat untuk memesan kembali produk sepatu specs.

Berdasarkan penelitian yang sudah dilaksanakan, terdapat beberapa keterbatasan didalam penelitian yaitu pertama, ruang lingkup dari penelitian yang hanya mencakup pada sepatu sepak bola merek Specs di Kota Denpasar sehingga tidak dapat menggambarkan perilaku niat beli ulang pelanggan sepatu sepak bola merek Specs secara umum di Bali. Kedua, faktor yang mempengaruhi niat beli ulang dalam penelitian ini adalah persepsi kualitas produk, pengalaman belanja online, dan akses informasi sedangkan masih banyak faktor lain yang bisa mempengaruhi niat beli ulang konsumen seperti citra merek, kualitas pelayanan, harga, kepuasa pelanggan ataupun faktor lainnya. Ketiga, penelitian ini hanya dilaksanakan dalam titik waktu tertentu (cross section), sedangkan lingkungan setiap saat dapat berubah (dinamis), sehingga penelitian ini penting untuk dilakukan lagi dimasa akan datang.

\section{SIMPULAN DAN SARAN}

Simpulan dari hasil penelitian berdasarkan hasil analisis dan pembahasan yang telah di paparkan adalah sebagai berikut, persepsi kualitas produk berpengaruh secara positif dan signifikan terhadap niat beli ulang pada sepatu sepak bola merek Specs di Kota Denpasar. Kemudian pengalaman belanja online berpengaruh secara positif serta signifikan terhadap niat beli ulang pada sepatu sepak bola merek Specs di Kota Denpasar. Serta akses informasi berpengaruh 
secara positif serta signifikan terhadap niat beli ulang pada sepatu sepak bola merek Specs di Kota Denpasar.

Saran yang dapat diberikan yang didasarkan atas hasil penelitian adalah untuk meningkatkan pengalaman belanja online pada sepatu sepak bola merek Specs, sebaiknya pihak manajemen Specs memberikan keterangan yang detail pada setiap produknya, sehingga konsumen tidak mendapatkan informasi yang salah. Kemudian pihak manajemen Specs sebaiknya memeriksa kembali dengan teliti barang yang akan dikirim sesuai dengan pesanan konsumen. Untuk meningkatkan akses informasi pada situs online sepatu sepak bola merek Specs menjadi lebih baik, maka sebaiknya pihak manajemen Specs dapat memberikan informasi yang selalu update kepada konsumen, sehingga dapat membuat konsumen tertarik melakukan pembelian ulang. Hasil penelitian ini diharapkan bisa mendorong peneliti lainnya untuk selanjutnnya dapat mempertimbangkan faktor pembanding lainya yang bisa mempengaruhi niat beli ulang konsumen, selain dari persepsi kualitas produk, pengalaman belanja online, dan akses informasi. Penelitian selanjutnya diharapkan bisa menambahkan jumlah sampel penelitian yang ada serta memperluas jangkauan wilayah dari sampel penelitian, dan memungkinkan untuk melakukan penelitian di keseluruhan Kabupaten/Kota Provinsi Bali sehingga hasil yang di dapatkan digeneralisasikan untuk lingkup yang lebih luas lagi.

\section{REFERENSI}

Alhasanah, J. U., Kertahadi dan Riyadi. (2014). Pengaruh Kegunaan, Kualitas Informasi Dan Kualitas Interaksi Layanan Web e-commerce Terhadap Keputusan Pembelian Online (Survei pada Konsumen www.getscoop.com). Jurnal Administrasi dan Bisnis (JAB). 15 (2). 
Durianto. (2004). Strategi Menaklukan Pasar Melalui Riset Ekuitas dan Prilaku Merek. Cetakan Ketiga. Jakarta : PT Gramedia Pustaka Utama.

Dutta, Soumitra; Dutton, William H dan Law, Ginette. (2011). “The New Internet World: A Global Perspective on Freedom of Expression, Privacy, Trust, and Security Online". Social Science Research Network.

Gendis T., H. Nurtjahjanti, I. Setywan, (2009). Correlation between perception via website on then students of psychology faculty, diponegoro University (Studies on Female students who have never bought fashion product via website). Journal Manajemen Bisnis. 4(2), pp:3-17.

Ghozali, Imam. (2006). Aplikasi Analisis Multivariate dengan program SPSS. Universitas Diponegoro: Semarang.

Halim, Cipta. (2010). Berbelanja Smart dan Membuka Gerai Gaul di Kaskus. Jakarta: PT Elex Media Computindo.

Huang, Y.C., Wu, J.Y.C., Wang, YC., and Boulanger, N.C. (2011). Decision making in online auctions. Management Decision, 49 (5), pp: 784-800.

Kim, J. and Park, J. (2005), A Consumer Shopping Channel Extension Model: Attitude Shift Toward the Online Store. Journal of Fashion Marketing \& Management. 9(1), pp:106-21.

Klein, L. (1998). Principle and Practice of Structural Equation Modeling, Guilford. New York, NY.

Kotler, Phillip and G. Armstrong. (2008). Principles of Marketing thirteen edition. New Jersey: Prentice-Hall, Inc.

Kristono, dan Honggo, H. (2010). Analisis Pengaruh Kualitas Informasi Website Terhadap Minat Beli Ulang Pelanggan Belanja Online. Jurnal STMIK GI $M D P$.

Kwon, Wi-Suk and Noh, Mijeong. (2010). The Influence Of Prior Experience And Age On Mature Consumers' Perceptions And Intentions Of Internet Apparel Shopping. Journal Of Fashion Marketing And Management: An International Journal. 14(3), pp:335-349

Ling, K.C., Chai, L.T., dan Piew, T.H., (2010), The Effects of Shopping Orientations, Online Trust and Prior Online Purchase Experience toward Customers'. Online Purchase Intention. International Business Research. 3(3), pp : 63-76

Martinez, Briana, and S. Kim. (2012). Predictings purchase intention for private sale sites". Emeraldinsight. 2(4), pp. 1361-2026. 
Meskaran, Fatemeh., Z. Ismail and B. Shanmugam. (2013). Online Purchases Intention: Effects of Trust and Security Perception. Australian Journal of Basic and Applied Sciences, 7(6), pp. 307-315.

Mohmed, A.S.I., Azizan N.B., and Jali, M.Z. (2013). The impact of trust and past experience on intention to purchase in e-commerce. International Journal of Engineering Research and Development, 7 (10): 28-35.

Nurtjahjanti, Harlina. (2010). Hubungan antara Persepsi terhadap Harga dan Kualitas Produk dgn Minat Membeli Produk Fashion online shop di Facebook pd mahasiswa Politeknik X Semarang". Jurnal Pemasaran. Fakultas Psikologi, Semarang: Universitas Diponegoro.

Oetomo, B. S. D. \& Santoso, S., (2015). Pengaruh Web Dalam Komunikasi Pemasaran Untuk Meningkatkan Perhatian dan Ketertarikan Konsumen Online. Jurnal EKSIS, 8 (2), pp:94-106.

Prastyaningsih, Ayu S., Suyadi, Imam., and E. Yulianto. (2014). Pengaruh Customer Experience Terhadap Repurchase Intention. Jurnal Administrasi Bisnis (JAB), 16(1), pp:1-8.

Rizki, K.H., Astuti, E.S., dan Susilo, H. (2015). Pengaruh Kemudahan dan Kualitas Informasi Terhadap Minat dan Keputusan Pembelian Secara Online (Survei Pada Konsumen www.ardiansmx.com). Jurnal Administrasi Bisnis (JAB), 28(1), hal: 56-63.

Setiowati Apriliani K., Widayat dan Jasly By. (2012). Sikap Online Shopping Dan Niat Pencarian Informasi Terhadap Niat dan Perilaku Belanja. Jurnal Manajemen Bisnis. 2(1), pp: 3-8.

Shaharudin, M. Rizaimy., A. Sabur bin Ismail., S. Wan Mansor., S. Janel Elias., M. Abdul Jalil. And M. Wan Omar. (2011). Innovative Food and Its Effects Toward Consumers' Purchase Intention of Fast Food Product. Journal Canadian Social Science. 7(1), Pp:110-118.

Shim, S., Eastlick, M.A., Lotz, S.L. and Warrington, P. (2001). An Online Prepurchase Intentions Model: The Role of Intention to Search. Journal of Retailing. 77(3), pp: 397-416.

Stevany, Grace. (2014). Analisis Produk Private Label Merek Kato Mempengaruhi Persepsi Kualitas Produk dan Berdampak pada Keputusan Pembelian di PT. Anugerah Kasih Sejati. Jurnal managemen.

Sugiyono. (2013). Metode Penelitian Pendidikan (Pendekatan Kuantitatif, Kualitatif dan $R \& D)$ ). Bandung: Alfabeta. 
Suki, N. M., (2013). Consumer shopping behaviour on the Internet: insights from Malaysia. Journal Electron Commer Res University Malaysia Sabah, pp. 477-491.

Suprapti, Ni Wayan. (2010) Perilaku Konsumen. Pemahaman Dasar dan Aplikasinya dalam Strategi Pemasaran. Denpasar: Udayana University Press.

Weisberg, Jacob, Dov Te'eni, and Limor Arman. (2010). Past Purchase and Intention to Purchase in E-Commerce: The Mediation of Social Presence and Trust. Internet Research, 21(1), pp: 82-96.

Wen, Chao; Prybutok, Victor.R dan Xu, Chenyan (2011). "An Integrated Model for Customer Online Repurchase Intention". Journal of Computer Information Systems. 52(1), pp:14-23.

Wolfinbarger, M. and Gilly, M. (2000). Shopping Online for Freedom, Control and Fun. California Management Review. 43(2), pp. 34-55.

Wulandari, Florentina Ratih. (2007). Dasar-Dasar Informasi. Jakarta: Universitas Terbuka.

Yuliati, L. N. \& Simanjuntak, S., (2011). Persepsi Manfaat dan Risiko Dalam Perilaku Pembelian Konsumen Online Shop. Jurnal Ilmiah Keluarga dan Konsumen, 4 (2), hal:173-181. 